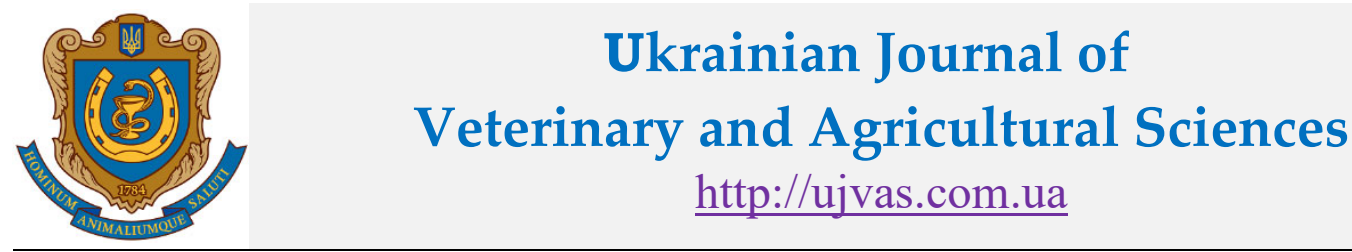

Stepan Gzhytskyi National University of Veterinary Medicine and Biotechnologies Lviv Stepan Gzhytskyi National University of Veterinary Medicine and Biotechnologies Lviv
original article

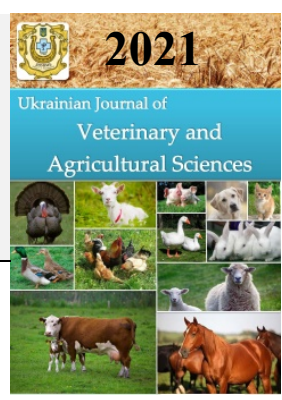

\title{
Histostructure of the gray matter of the spinal cord in cattle (Bos Taurus)
}

\author{
I. M. Sokulskyi ${ }^{1}$, L. P. Goralskyi ${ }^{1}$, N. L. Kolesnik ${ }^{1}$, O. F. Dunaievska ${ }^{1}$, N. L. Radzikhovsky ${ }^{2}$ \\ ${ }^{1}$ Polissia national university, Staryj Boulevard, 7, Zhytomyr, 10002, Ukraine \\ ${ }^{2}$ National University of Life and Environmental Sciences of Ukraine, Heroiv Oborony str., 15, Kyiv, 03041, Ukraine
}

\begin{tabular}{l} 
Article info \\
Received 28.06.2021 \\
Received in revised form \\
30.07 .2021 \\
Accepted 31.07.2021 \\
\hline Correspondence author \\
Ihor Sokulskyi \\
Tel.: +38-097-785-73-20 \\
E-mail: sokulskiy_1979@ukr.net \\
\hline
\end{tabular}

2021 Sokulskyi I. et al. This is an open-access article distributed under the terms of the Creative Commons Attribution License, which permits unrestricted use, distribution, and reproduction in any medium, provided the original author and source are credited.

\section{(cc) BY}

\section{Contents}

1. Introduction

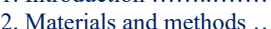

$\begin{array}{ll}\text { 3. Results and discussion ....... } & 12 \\ \text {. }\end{array}$

4. Conclusions ............... 14

References ..................... 14

\begin{abstract}
The scientific article presents the results of investigating the spinal cord's morphology of a domestic bull (Bos Taurus). Data on the histo- and cytostructure of the spinal cord are given according to the results of histological, neurohistological, and morphometric studies. For their implementation, the selected material $($ spinal cord $\mathrm{n}=8)$ was subjected to fixation in 10-12\% neutral formalin solution, followed by pouring into paraffin. Histological sections were made from paraffin blocks on a sliding microtome MS-2 with a thickness of not more than ten $\mu$ m. Staining of sections with hematoxylin and eosin, according to Van Gieson's methods, as well as neuro-histological methods of impregnation of nerve tissue with silver nitrate according to the Bilshovskym-Gross method, was used for the morphometric studies, investigating the morphology of the cell, conducting and obtaining the review histological preparations. The histostructure of the spinal cord, the localization of neurons in the gray matter, and morphometric studies of structural elements were examined on histological specimens by light microscopy. The entire experimental part of the research was conducted following the requirements of the international principles of the "European Convention for the Protection of Vertebrate Animals for Experimental and Other Scientific Purposes" (Strasbourg, 1986). The spinal cord, medulla spinalis, an organ of the central nervous system of vertebrates, is located in the spinal canal. The spinal cord is protected externally by soft, arachnoid, and hard meninges. The space between the membranes and the spinal canal is filled with cerebrospinal fluid. It is well known that groups of multipolar nerve cells with the same functional value form the nuclei of the gray matter of the spinal cord. According to the results of our histological studies, a pronounced differentiation of nerve cells, which have different shapes and sizes. Among them are large, medium, and small nerve cells. The shape of nerve cells is different, which, in turn, depends on their location in certain areas of the gray matter of the spinal cord and the size of the cell. In general, there are multifaceted, stellate, spindle-shaped, elongated, rounded, and oval neurons. Small nerve cells have an oval or round, less often - irregularly rounded shape, medium - round, oval, spindle-shaped. Large nerve cells are dominated by a multifaceted shape with distinct processes. The nuclei of large nerve cells, in most cases, have a rounded shape, less often - oval, mostly in the center of the cells, seldom - eccentrically. According to the results of morphological studies, it is noted that the neurons of the gray matter of the spinal cord have different shapes and sizes. Consequently, in the gray matter, small cells are the highest quantity $(47.91 \pm 0.32 \%)$ of the total number of nerve cells. The second place is occupied by average neurons $(33.70 \pm 0.46 \%)$. The large cells are detected in the smallest amount $(18.37 \pm 0.50 \%)$.
\end{abstract}

Keywords: animals, cattle, morphology, histological structure, spinal cord, nervous system, neuron, cytoplasm, neurocytic organization.

\section{Citation:}

Sokulskyi, I. M., Goralskyi, L. P., Kolesnik, N. L., Dunaievska, O. F., \& Radzikhovsky, N. L. (2021). Histostructure of the gray matter of the spinal cord in cattle (Bos Taurus). Ukrainian Journal of Veterinary and Agricultural Sciences, 4(3), 11-15.

\section{Introduction}

Intensive cattle' dairy and beef breeding in Ukraine and countries far and near abroad takes a significant priority (Patel \& DuPont, 2015; Bomko et al., 2018; Sachuk et al., 2019; Sidashova et al., 2020) and requires from a veterinarian professional knowledge of the norms and pathology of systems and their organs in the body as a whole, which will make an objective conclusion about the health of the animal (Gutyj et al., 2017; Kulyaba et al., 2019; Stravsky et al., 2020). Increasing the productivity of animals, namely increasing the quantity and quality of products, preserving their genetic potential by preventing the emergence and spread of cattle' diseases, depends on a set of preventive measures and examination of morphological parameters at the macro-and microscopic level at a normal level (Klosova et al., 2019; Borshch et al., 2020).

An important role in the body's functioning is the nervous system, which is constantly subject to the influence of internal and external conditions in which the body is (Sysyuk et al., 2017; Zhurenko et al., 2018).

The actuality of theme. Many issues related to the development of species, comparative morphology of vertebrates remain at the level of accumulation of factual materials despite the significant achievements of domestic and foreign researchers in vertebrate morphology (Freire et al., 2008). This is especially true of the morphology of the nervous system of domestic animals, in particular, the central nerv- 
ous system (Danchuk et al., 2017). Adaptation of the organism to changes in these living conditions occurs primarily with the participation of the nervous system. The doctrine of the structural and functional organization of the spinal cord is constantly supplemented by new data that help to understand the patterns of its neural structure and function as an organ of the central nervous system. The spinal cord is a complex and highly organized structure in functional terms, which can play a significant role in the sensory-motor integration of the organism (Popele \& Bosco, 2003; Shkolnikov et al., 2018). The structure of each of the departments of the central nervous system, obeying the general laws, has features, knowledge of which is necessary for the clinical practice of neurologists, neurosurgeons, and more.

Thus, given the importance of the functioning of the spinal cord of domestic animals, it is relevant in the study of its morphological structure, which can be used as a criterion for physiological norms in various diseases of infectious and non-infectious pathology.

\section{Materials and methods}

Morphological studies were performed at the Department of Anatomy and Histology, Faculty of Veterinary Medicine, Polissya National University.

The research work is a fragment of the complex scientific program of the relevant department on the topic: "Marker signs of development of immunogenetic and nervous system of vertebrates in onto- and phylogeny" (state registration number - № 0120U102370).

During the research, the basic rules of good laboratory practice GLP (1981), the provisions of the "General ethical principles of animal experiments", adopted by the First National Congress of Bioethics (Kyiv, 2001), were followed. The entire experimental part of the study was conducted following the requirements of the international principles of the "European Convention for the protection of vertebrate animals used in experiments and other scientific purposes" (Strasbourg, 1986). "On measures to further improve the organizational forms of work with the use of experimental animals" and the relevant law "On protection of animals from cruel treatment” (№ 3447-IV of 21.02.2006, Kyiv) (Yablonska, 2019).

For histological and neurohistological examinations of cattle, immediately after the death of animals, the spinal cord of the thoracic segments was prepared at the level of Th4-Th6 at the slaughterhouse in Zhytomyr. Adult animals were slaughtered. The material was fixed in $10 \%$ neutral formalin solution, Carnois solutions, and $96^{\circ}$ ethyl alcohol. Then the recorded material was subjected to dehydration and paraffin infiltration according to the scheme proposed in the manual of L. P. Goralsky (Horalskyi et al., 2019). Histosections were made with a thickness of not more than ten $\mu \mathrm{m}$ from paraffin blocks.

The staining of sections with hematoxylin and eosin and Van Gieson 's methods was used to study the microscopic structure, cell morphology, morphometric study and to obtain review preparations.
The neurofibrillary apparatus in nerve cells was detected using neurohistological research methods (silver impregnation according to the Bilshovskym-Gross method, total impregnation according to Ramón-y-Cajal).

To detect basophilic granularity (basophilic substance, chromatophilic substance, Nissl substance) in neuroplasm, nuclei of nerve cells, and neuroglia cells, Nissl's staining was used.

Histometric studies of histological specimens were performed using microscopes "Micros" and MBS-10 under the recommendations for morphometric studies (Horalskyi et al., 2019).

Microphotography of histological specimens was performed using a Micros MC50 microscope with a built-in video camera CAM V200 connected to a personal computer and an MBS-10 microscope with a Canon digital camera.

\section{Results and discussion}

Analysis of the results of our research and their comparison with the literature indicates that the histological structure of the spinal cord of the studied animals is similar to other species of mammals. It has the form of a cylindrical cord compressed dorsoventrally. It is the basis of a segmental structure characterized by a metameric distribution of its gray matter, which is associated with certain areas of the skin - dermatomes, internal organs - splanchnotoms and muscles - myotomes. Thus, the segmental structure of the gray matter provides morphological data on the lamellar structure of the spinal cord and morphofunctional characteristics of the cell structure (Porseva \& Shilkin, 2016). The gray matter of the spinal cord is localized in the center and in the section that resembles the letter " $\mathrm{H}$." The gray matter is divided into paired dorsal and ventral horns, which are connected by a gray adhesive. The lateral horn is located between the dorsal and ventral horns in the thoracolumbar regions (Fig. 1). Gray matter is represented by the bodies of nerve cells and their processes, nerve endings with synaptic apparatus, macro-and microglia, and vessels. White matter surrounds the gray matter and is formed by bundles of pulp nerve fibers that form conductive pathways throughout the spinal cord.

In recent years, much attention has been paid to identifying the structural and functional characteristics of neurons of the gray matter of the spinal cord, the heterogeneity of which goes far beyond the existing ideas about their division into appropriate topographic zones (Stepien et al., 2010; Porseva \& Shilkin, 2016). However, throughout the spinal cord, the specific structure of the gray matter is visible, which also depends on the department and segment of the spinal cord (Tang et al., 2003).

Our studies of the microscopic structure of the gray matter of the spinal cord of cattle have shown a pronounced differentiation of nerve cells that have different shapes and sizes. The large, medium, and small neurons are located among them (Fig. 2). The shape of nerve cells is different, which depends on their topographic location in certain areas of the gray matter of the spinal cord and the morphofunctional state of cells and their size. 


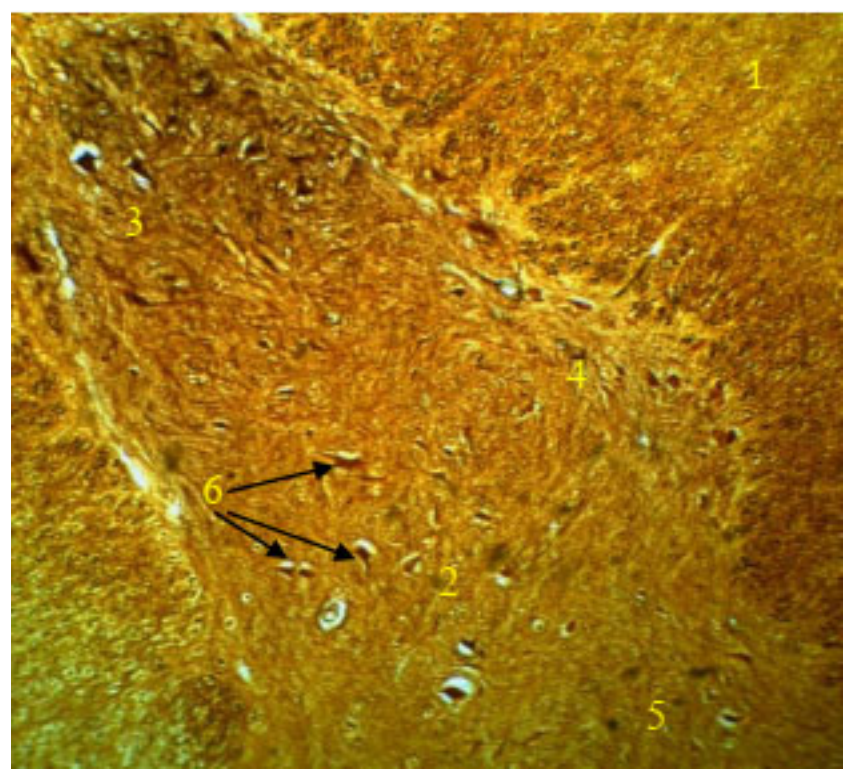

Fig. 1. A fragment of the microscopic structure of the spinal cord of mature cattle: 1 - white matter; 2 - gray matter; 3 - dorsal horn; 4 - lateral horn; 5 - ventral horn; 6 - nerve cells. Ramón-y-Cajal. $\times 120$

The spinal cord's dorsal horns in cattle are represented, for the most part, by small neurons with barely visible processes. There are also single nerve cells of large size with pronounced processes and the presence of rounded nuclei, which are located eccentrically.

Dorsolaterally from the central canal at the base of the dorsal horn is the thoracic, or dorsal, Clarke's nucleus of oval shape. However, there is no consensus on its topography (Nogradi \& Vrbova, 2006). In large animals, the dorsal nucleus is located dorsolaterally from the central canal at the level of segments $\mathrm{C}_{8}-\mathrm{L}_{3}$ (Eustachiewicz et al., 1980). Nuclei have a variety of shapes: pear-shaped, star-shaped, oval, etc. and different sizes: medium neurons $20-30 \mu \mathrm{m}$ in diameter, large - respectively $30-40 \mu \mathrm{m}$ in some vertebrates (Mann, 1973). The diversity of the cell composition of the dorsal nucleus in animals is due to the multifunctionality of its neurons, which provide convergence of sensory pathways. The Clarke's dorsal nucleus of gray matter in cattle is formed by single large neurons of irregular, multifaceted shape, with distinctly long processes and eccentrically placed nuclei. It also detects middle neurons, which are located close to large neurons. They have an elongated shape with pronounced processes. The nuclei of such nerve cells are located eccentrically. At the same time, small round neurons with distinct large round and irregularly rounded nuclei, which are located eccentrically, are isolated.

The structural organization of Clarke's dorsal nucleus neurocytes is characterized by a light neuroplasm and a dense network of neurofibrils, which are located in the neuroplasm of cells and the processes. The nucleoli of such neurons, which have different sizes, have a weak pronounced color. Single neurons of medium size with clear processes are situated closer to the gray commissure and the central canal.

Glial cells of the gray matter are unevenly distributed uniformly near the nerve cells.

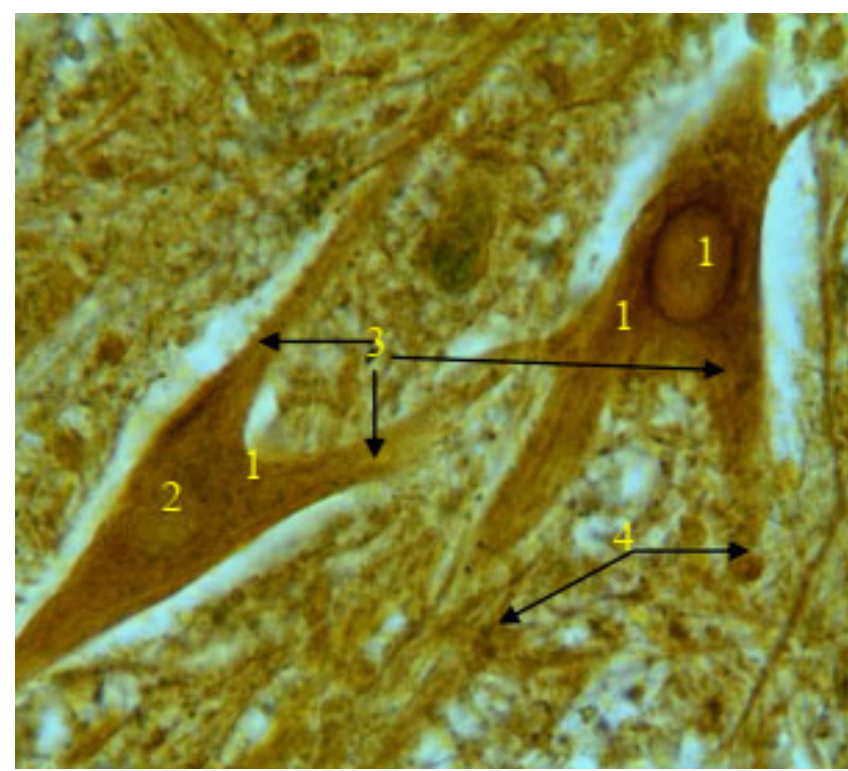

Fig. 2. A fragment of the microscopic structure of the gray matter of the spinal cord of mature cattle: 1 - the body of the neuron; 2 - cell nucleus; 3 - a process of nerve cell;

4 - nuclei of glial cells. Bilshovskym-Gross. $\times 400$

The intermediate-lateral nucleus is located in the intermediate zone of the thoracolumbar spinal cord (Fig. 3), which includes morphologically different groups of cells that combine into nuclei (Clarke et al., 1998; Deuchars et al., 2005). Our studies show that single diffusely scattered small neurons represent nerve cells of the intermediate zone of the lateral horn. Medium and large nerve cells are often located together and form groups in most of the three neurons. Such cells have an elongated or star-shaped shape, mostly with eccentrically placed nuclei. Their processes are expressed at the base of the neuron. Glial cells rarely come into contact with cell neurolemma.

The localization of neurons in the ventral horns is represented by motoneurons, located near the horn's lateral and ventromedial surface. Motoneurons differ from other neurons in size, the multipolar shape of cell bodies (Molander et al., 1989). The ventral horns of the gray matter of the spinal cord of cattle are represented by extremely large nerve cells, the volume of which is from 21455.78 to $39788.58 \mu \mathrm{m}^{3}$.

Large motoneurons, which have mainly a multifaceted, star-shaped shape and a pronounced large nucleus, are located in groups of 4 to 8 neurons in the central zone of the ventral horn. Neurons of medium size, oval, oblong, are often located singly in the central zone and near large neurons. Small nerve cells of round and oval shape are scattered throughout the central zone. Such neurons in lateral and medial areas are placed in groups of $2-3$ cells.

Ventral glial cells are unevenly spaced uniformly near nerve cells. The highest density of such cells is characteristic of medium-sized neurons. The density of glial and nerve cells and their relationship characterize the dynamics of brain development and is a morphological sign of physiological and pathological changes in the nervous system.

On sections of the spinal cord stained with toluidine bruise, in the cytoplasm of nerve cells, there is a uniformly distributed basophilic granularity, which is significantly larger in the nuclei of the ventral horns (Fig. 4). 


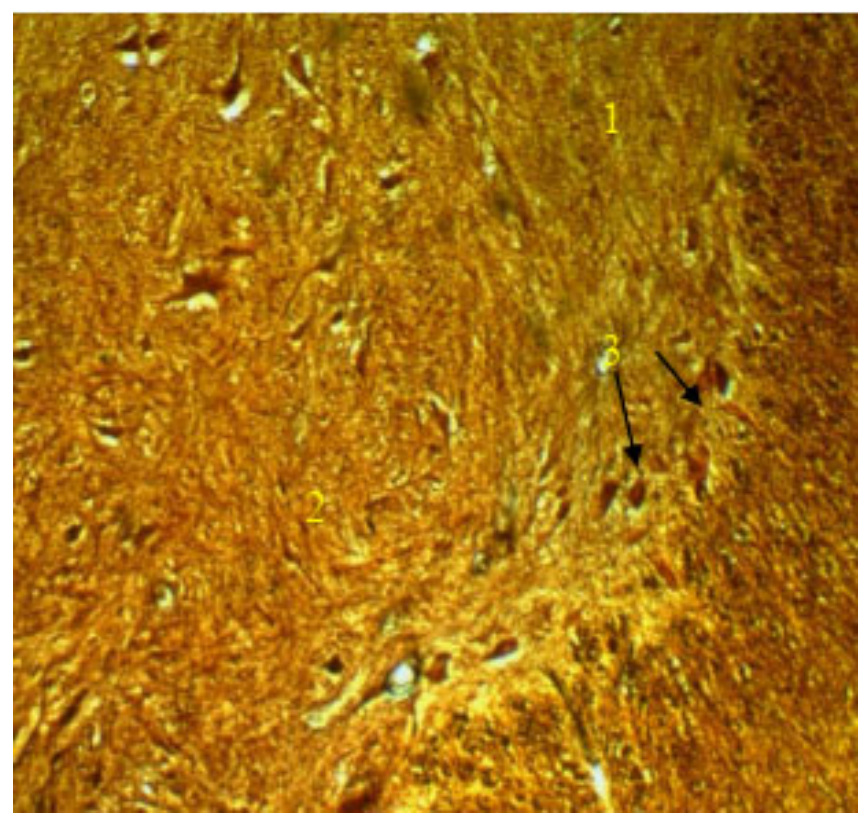

Fig. 3. A fragment of the microscopic structure of the gray area of mature cattle: 1 - gray matter; 2 - lateral horn;

3 - nucleus of a lateral horn. Ramón-y-Cajal. $\times 120$

According to the results of studies of the microscopic structure of the gray matter of the thoracic spinal cord of the studied animals, a pronounced differentiation of nerve cells of different shapes and sizes was established. Among them are small, medium, and large nerve cells, the ratio of which in the gray matter of the spinal cord of the studied animals is different. Thus, the percentage of small neurons in cattle is the most common $-47.91 \pm 0.32 \%$. Medium and large neurons account for $33.70 \pm 0.46 \%$ and $18.37 \pm 0.50 \%$.

The results of morphometric studies indicate that the average volume of small nerve cells in the thoracic spinal cord of cattle is $632.366 \pm 47.166 \mu^{3}$; medium $-4155.599 \pm$ $209.354 \mu^{3}$; large $-20384.769 \pm 1302.752 \mu \mathrm{m}^{3}$. The mean volume of nerve cells is $9981.042 \pm 778.754 \mu \mathrm{m}^{3}$. The volume of the nuclei is, respectively, $61.696 \pm 6.551 \mu^{3}$; $287.221 \pm 24.393 \mu^{3} ; 920.498 \pm 60.471 \mu^{3}$, and $503.970 \pm$ $35.377 \mu^{3}$. The nuclear-cytoplasmic ratio is different and depends on the size of the cells and their nuclei. Thus, the highest rate of nuclear-cytoplasmic ratio in all cases is found in small neurons $-0.107 \pm 0.008$, then in medium $-0.071 \pm$ 0.005 , and the lowest - in large nerve cells $-0.054 \pm 0.003$.

\section{Conclusions}

The research allows defining the morphofunctional characteristic of neurons of the gray matter of a spinal cord of mature cattle. Neurocytic organization of the corresponding structures is characterized by the presence of the large, medium, and small nerve cells with different nuclearcytoplasmic ratios: the highest rate of nuclear-cytoplasmic ratio in all cases is found in small nerve cells $-0.107 \pm$ 0.008 , the smallest - in large cells $-0.054 \pm 0.003$. Such morphological parameters of neurons serve as a criterion for determining the morphofunctional state of cells.

Prospects for further research aimed at conducting the ultramicroscopic examination of the nervous system, in particular the spinal cord of a domestic bull.

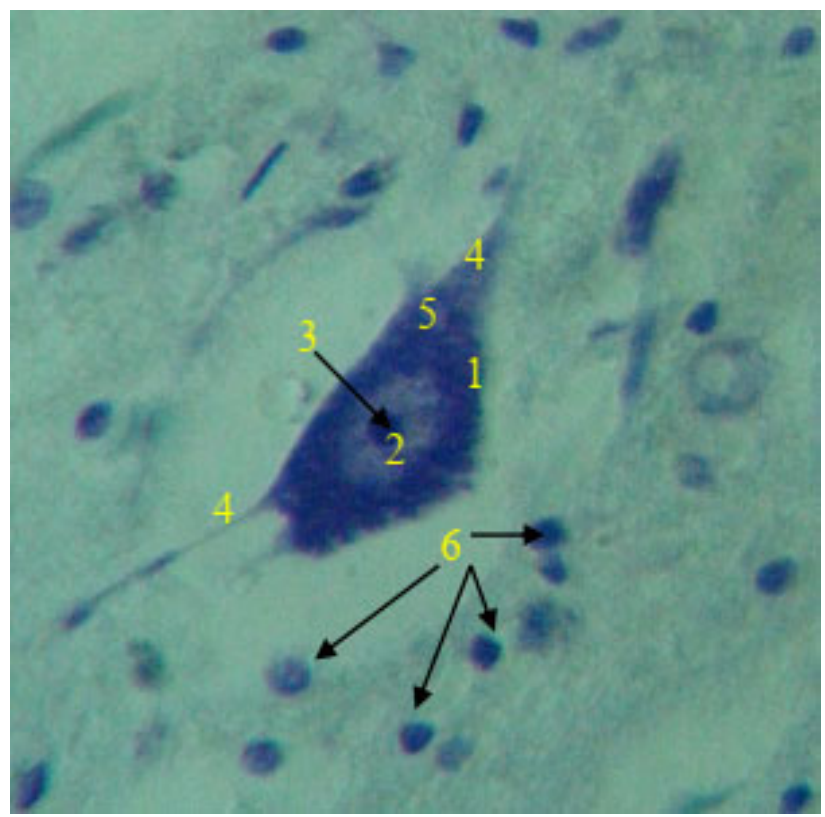

Fig. 4. Fragment of the microscopic structure of the gray matter of the spinal cord of mature cattle: 1 - nerve cell; 2 - the nucleus of the nerve cell; 3 - nucleolus; 4 - nerve cell process; 5 - basophilic granularity; 6 - neuroglia cells. Nissl. $\times 400$

\section{Conflict of interest}

The authors declare that there is no conflict of interest.

\section{References}

Bomko, V., Kropyvka, Yu., Bomko, L., Chernyuk, S., Kropyvka, S., \& Gutyj, B. (2018). Effect of mixed ligand complexes of Zinc, Manganese, and Cobalt on the Manganese balance in highyielding cows during the first 100-days lactation. Ukrainian Journal of Ecology, 8(1), 420-425. DOI: 10.15421/2018_230.

Borshch, O. O., Gutyj, B. V., Sobolev, O. I., Borshch, O. V., Ruban, S. Yu., Bilkevich, V. V., Dutka, V. R., Chernenko, O. M., Zhelavskyi, M. M., \& Nahirniak, T. (2020). Adaptation strategy of different cow genotypes to the voluntary milking system. Ukrainian Journal of Ecology, 10(1), 145-150. DOI: 10.15421/2020_23.

Clarke, H. A., Dekaban, G. A., \& Weaver, L. C. (1998). Identification of lamina V and VII interneurons presynaptic to adrenal sympathetic preganglionic neurons in rats using a recombinant herpes simplex virus type 1. J. Neurosci, 85(3), 863-872. DOI: 10.1016/s0306-4522(97)00658-1.

Danchuk, O. V., Karpovskyi, V. I., Trokoz, V. O., \& Postoi, R. V. (2017). Regulation mechanisms of cortisol level in pigs' blood serum under stress. Fiziol. Zh., 63(6), 60-65. DOI: $10.15407 /$ fz63.06.060.

Deuchars, S. A., Milligan, C. J., Stornetta R. L., Deuchars, J., \& Deuchars, S. A. (2005). GABAergic neurons in the central region of the spinal cord: a novel substrate for sympathetic inhibition. Neurosci, 25(5), 1063-1070. DOI: 10.3389/fneur.2010.00142.

Eustachiewicz, R., Flieger, S., Boratyński, Z., \& Sławomirski, J. (1980). Structure and topography of nucleus dorsalis in the spinal cord of horses. Pol. Arch. Weter, 21(4), 499-506. URL: https://pubmed.ncbi.nlm.nih.gov/7208374.

Freire, M. A. M., Tourinho, S. C., Guimarães, J. S. [et al.]. (2008). Histochemical characterization, distribution, and morphometric analysis of NADPH diaphorase neurons in the spinal cord of the agouti. Front. Neuroanat, 2, 1-8. DOI: 10.3389 /neuro.05.002.2008.

Gutyj, B., Grymak, Y., Drach, M., Bilyk, O., Matsjuk, O., Magrelo, N., Zmiya, M., \& Katsaraba, O. (2017). The impact of endogenous intoxication on biochemical indicators of the blood of pregnant cows. Regulatory Mechanisms in Biosystems, 8(3), 438-443. DOI: 10.15421/021768. 
Horalskyi, L. P., Khomych, V. T., \& Kononskyi, O. I. (2019) Osnovy histolohichnoi tekhniky i morfofunktsionalni metody doslidzhennia u normi ta pry patolohii [Fundamentals of histological technique and morphofunctional research methods in normal and pathological conditions] Polissia, Zhytomyr (in Ukrainian).

Klosova, X. G., Bushueva, I. V., Parchenko, V. V., Shcherbyna, R. O., Samura, T. O., Gubenko, I. Ya., Gutyj, B. V., \& Khariv, I. I. (2019). Trifuzol Suppositories Usage Results On The Course Of Endometrial Inflammatory Processes In Cows. Research Journal of Pharmaceutical, Biological and Chemical Sciences, 10(1), 1215-1223. URL: https://www.rjpbcs.com/pdf/ 2019 10(1)/[157].pdf.

Kulyaba, O., Stybel, V., Gutyj, B., Turko, I., Peleno, R., Turko, Ya., Golovach, P., Vishchur, V., Prijma, O., Mazur, I., Dutka, V., Todoriuk, V., Golub, O. Dmytriv, O., \& Oseredchuk, R. (2019). Effect of experimental fascioliasis on the protein synthesis function of cow liver. Ukrainian Journal of Ecology, 9(4), 612-615. URL: https://www.ujecology.com/abstract/effect-of-experimentalfascioliasis-on-the-protein-synthesis-function-of-cow-liver-44972. HTML.

Mann, M. D. (1973). Clarke's column and the dorsal spinocerebellar tract: a review. Brain Behavior and Evolution, 7(1), 34-83. DOI: $10.1159 / 000124397$.

Molander, C., Xu, Q., Rivero-Melian, C., \& Grant, G. (1989). Cytoarchitectonic organization of the spinal cord in the rat: II. The cervical and upper thoracic cord. J. Comp. Neurology, 289, 375-385. DOI: 10.1002/cne.902890303.

Nogradi, A., \& Vrbova, G. (2006). Anatomy and physiology of the spinal cord. Transplantation of Neural Tissue into the Spinal Cord, 2, 1-23. DOI: 10.1007/0-387-32633-2 1.

Patel, R., \& DuPont, H. L. (2015). New approaches for bacteriotherapy: Prebiotics, new-generation probiotics, and synbiotics. Clin. Infect. Dis., 60(2), 108-121. DOI: 10.1093/cid/civ177.

Popele, R, \& Bosco, G. (2003). Sophisticated spinal contributions to motor control. Trends Neurosci, 26(5). 269-276. DOI: 10.1016/S0166-2236(03)00073-0.

Porseva, V. V., \& Shilkin, V. V. (2016). Stroenie serogo veshchestva spinnogo mozga: neopredelennosti i perspektivy issledovaniya. Tihookeanskij medicinskij zhurnal, 2, 20-30 (in Russian).

Sachuk, R. M., Stravsky, Ya. S., Katsaraba, O. A., Zhigalyuk, S. V., Kulinich, O. V., \& Kushnir, M. I. (2019). Monitoring of obstetric pathology of cows in agricultural enterprises of Rivne region. Scientific Messenger of Lviv National University of Veterinary Medicine and Biotechnologies. Series: Veterinary Sciences, 21(96), 117-123. DOI: 10.32718/nvlvet9621.

Shkol'nikov, V. S., Prihod'ko, S. O., \& Ocheretnyuk, A. O. (2018). Suchasnyi pohliad shchodo strukturnoi orhanizatsii spynnoho mozku liudyny. Visnyk problem biolohii i medytsyny, 4(2), 9395 (in Ukrainian).

Sidashova, S. O., Gutyj, B. V., Khalak, V. I., \& Humeny, O. G. (2020). Influence of complex action of probiotic and specific prophylaxis of associated mucosal diseases on some quantitative traits of dairy cattle performance. Scientific Messenger of Lviv National University of Veterinary Medicine and Biotechnologies. Series: Veterinary Sciences, 22(97), 79-87. DOI: 10.32718/nvlvet9714.

Stepien, A. E., Tripodi, M., \& Arber, S. (2010). Monosynaptic rabies virus reveals premotor network organization and synaptic specificity of cholinergic partition cells. Neuron, 68, 456472. DOI: 10.1016/j.neuron.2010.10.019.

Stravsky, Ya. S., Boltyk, N. P., Sachuk, R. M., Serheyev, V. I., \& Rushchynska, T. M. (2020). The content of total protein and protein fractions in cows during pregnancy and their diagnostic value. Scientific Messenger of Lviv National University of Veterinary Medicine and Biotechnologies. Series: Veterinary sciences, 22(99), 198-202. DOI: 10.32718/nvlvet9930.

Sysyuk, Y., Karpovskiy, V., Zhurenko, O., Danchuk, O., \& Postoy, R. (2017). Zminy v vitaminnii lantsi antyoksydantnoi systemy koriv riznykh typiv vyshchoi nervovoi diialnosti. Naukovyi visnyk LNU veterynarnoi medytsyny ta biotekhnolohii, 19(78), 81-85. doi: 10.15421/nvlvet7816 (in Ukrainian).

Tang, X., Neckel, N. D., \& Schramm, L. P. (2003). Locations and morphologies of sympathetically correlated neurons in the T10 spinal segment of the rat. Brain Res, 976, 185-193. DOI: 10.1016/s0006-8993(03)02601-5.

Yablons'ka, O. V. (2019). Vykorystannia laboratornykh tvaryn u eksperymentakh: metod. Vkazivky. K.: Vid. centr NAU, 3-16. (in Ukrainian).

Zhurenko, O. V., Karpovskiy, V. I., Danchuk, O. V., \& Kravchenko-Dovga, Yu. V. (2018). The content of calcium and phosphorus in the blood of cows with a different tonus of the autonomic nervous system. Scientific Messenger of Lviv National University of Veterinary Medicine and Biotechnologies, 20(92), 8-12. DOI: 10.32718/nvlvet9202. 